\title{
Commentary: Cross my heart and stick a needle in it-I hope to live
}

\author{
Ronald K. Woods, MD, PhD
}

\footnotetext{
From the Division of Pediatric Cardiothoracic Surgery, Department of Surgery, Medical College of Wisconsin, Milwaukee, Wis; and Herma Heart Institute, Children's Hospital of Wisconsin, Milwaukee, Wis. Disclosures: Author is cofounder of OperVu, Inc which has no relationship to the content of this work.

Received for publication June 10, 2019; accepted for publication June 11, 2019; available ahead of print July 16, 2019.

Address for reprints: Ronald K. Woods, MD, PhD, Division of Pediatric Cardiothoracic Surgery, Department of Surgery, Medical College of Wisconsin, Children's Hospital of Wisconsin, 9000 W Wisconsin Ave, MS B 730, Milwaukee, WI 53226 (E-mail: rwoods@chw.org).

J Thorac Cardiovasc Surg 2019;158:1626

$0022-5223 / \$ 36.00$

Copyright $(2019$ by The American Association for Thoracic Surgery

https://doi.org/10.1016/j.jtcvs.2019.06.021
}

In this issue of the Journal, Burkhart and colleagues ${ }^{1}$ report results of a phase I trial designed to assess safety and feasibility of epicardial injections of umbilical cord bloodderived mononuclear cells in 10 patients with hypoplastic left heart syndrome at the time of stage II (Glenn) palliation. ${ }^{1}$ If we accept the premise that delivery of the right cell types in the right amount to the young infant myocardium will provide durable and clinically relevant benefit, then this work is important. Burkhart and colleagues ${ }^{1}$ have developed and refined a method of umbilical cord blood harvest and processing that provides a reliable product at the time of the Glenn palliation-a significant achievement resulting from years of determined hard work. Overall, the success rate of producing this autologous source was $80 \%$; reaching more than $90 \%$ when more than $35 \mathrm{~mL}$ of cord blood was available. The technique of epicardial injection is simple and is done after heparin reversal. This contrasts with the method of intracoronary injection of cardiosphere-derived cells months after the procedure, predominantly in older children, in the phase II PERSEUS (Cardiac Progenitor Cell Infusion to Treat Univentricular Heart Disease) trial. ${ }^{2}$ Both trials reveal the sobering challenges of patient accrual-10 of 60 patients completed the current trial of Burkhart and colleagues ${ }^{1}$; 34 of 110 patients completed the PERSEUS trial.

Despite the low patient numbers, I am inclined to agree with the conclusion of Burkhart and colleagues ${ }^{1}$ that the data support feasibility and safety and the progression to phase II. I also respect the fact that these investigators refrained from including any data or implications about efficacy in a safety and feasibility trial. I am somewhat curious about the case of a patient with necrotizing enterocolitis (NEC) — a highly atypical event in a carefully selected cohort of Glenn procedures without patients at high risk for serious complications (last exclusion criterion). Although the death was attributed to complications related to the colostomy takedown, NEC was the proximate event. Other than

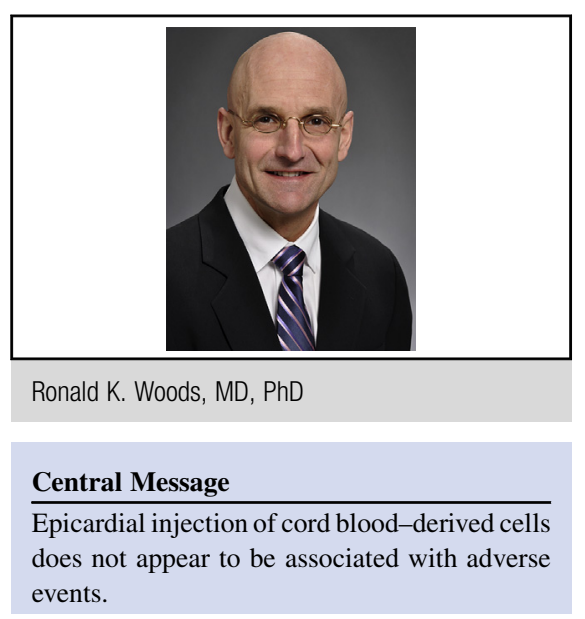

See Article page 1614.

specifying an adverse event reporting period of 30 days, Burkhart and colleagues ${ }^{1}$ do not provide a more precise time of the occurrence of NEC. Unless I have misread the article, the patient's cardiac function was reported as normal at 3 months at the time of colostomy takedown. There is no information about early postoperative cardiac function, systemic oxygen saturations, or estimates of cardiac output that might help explain why this patient had NEC occur.

I acknowledge the courage and fortitude required to overcome what must have been numerous challenges and obstacles to organizing and conducting this trial, and I offer my encouragement for the phase II trial. As this and similar such trials progress, we, as a clinical specialty, and society at large should be prepared for the challenge of defining the success or value of such therapies. As simple, hypothetical examples, how does an ejection fraction of $55 \%$ versus $50 \%$ at 1 year translate into long-term freedom from death or transplant? What is the ultimate benefit of a slight upward shift in the growth curve? And what are we willing to pay for these improvements? Let us hope that the success of investigations requires that we provide the answers.

\section{References}

1. Burkhart HM, Qureshi MY, Rossano JW, Peral SC, O'Leary PW, Hathcock M, et al. Autologous stem cell therapy for hypoplastic left heart syndrome: safety and feasibility of intraoperative intramyocardial injections. J Thorac Cardiovasc Surg. 2019;158:1614-23.

2. Ishigami S, Ohtsuki S, Eitoku T, Ousaka D, Kondo M, Kurita Y, et al. Intracoronary cardiac progenitor cells in single ventricle physiology: the PERSEUS (cardiac progenitor cell infusion to treat univentricular heart disease) randomized phase 2 trial. Circ Res. 2017;120:1162-73. 